\title{
PERBANDINGAN PENGARUH SUKU BUNGA DAN INFLASI TERHADAPKREDITDAN PEMBIAYAAN (Studi Kasus pada Bank Umum Konvensional dan Bank Umum Syariah periode 2011-2015)
}

\author{
Hasannudin Nursalim Putra \\ Irnin Miladyan Aryq \\ Lilik Jazilatul Mufidah \\ Fakultas Ekonomi UIN Maulana Malik Ibrahim Malang
}

\begin{abstract}
Inflationary pressures that often time there was a can shake economy the state, to face inflationary pressures one of the efforts of the country to control the inflation is by issuing policy interest rate by the Indonesia bank as central financial policy monetary and fiscal. The banks have the role of to control the rate inflation. The interest rate that set by the bank will affect the level distribution credit of bank conventional and financing of sharia bank. For that researchers want to see the influence of direct and indirect interest rates to credit and financingand inflation as variable intervening. The kind of research is quantitative with the sample of six general Sharia Bank and the generalconventional bank in Indonesia period 2011 until 2015 taken with purposive sampling. Themethod is path analysis. Based onsignificant test, the first significant test has result that interest rates significant of inflation. Thesecond significant testhas results that the interest rate not significant on the distribution credit and financing. The third significant test has result that inflation is not significant to distribution credit and financing. So this is can concluded that inflation will not be variable intervening for the distribution credit and financing.
\end{abstract}

Keywords: interest rate, inflation, credit, financing

Dewasa ini terjadi kenaikan harga barang secara serentak terutama terhadap barang komoditas, ini merupakan sebuah ancaman bagi setiap Negara baik itu Negara berkembang maupun Negara maju. Tekanan inflasi yang sering kali terjadi dapat menggoncangkan perekonomian Negara. Maka untuk menghadapi tekanan inflasi ini, salah satu upaya Negara adalah dengan mengeluarkan kebijakan terkait dengan suku bunga. Suku bunga ditetapkan oleh Bank Indonesia sebagai pusat kebijakan keuangan moneter maupun fiskal. Menurut data yang dirilis oleh Bank Indonesia menunjukkan bahwa inflasi dan BI rate yang terjadi sejak tahun 2011 sampai 2015 mengalami perubahan.

Kehadiran perbankan di Indonesia diperlukan guna ikut mengontrol laju inflasi yang terjadi di Indonesia. Dalam UU No 23 th 1999 pasal 10 ditegaskan bahwa Bank Indonesia memiliki kewenangan untuk melaksanakan kebijakan moneter melalui penetapan sasaran moneter dengan memerhatikan sasaran laju inflasi (Latumaerissa, 80:2013). Menurut teori Fisher mengenai tingkat bunga riil, yang didasarkan atas pengamatan jangka panjang berlaku tingkat bunga dan laju inflasi di Amerika Serikat mengatakan bahwa "Dalam jangka panjang, tingkat bunga riil tidak dipengaruhi oleh laju inflasi" (Boediono, 91:2014).

Lebih lanjut, Islam memberikan dorongan untuk melakukan investasi dengan jumlah yang lebih besar dan lebih banyak dari motivasi konvensional.Kalau secara konvensional terdapat motif profit-taking dan inflasi, dalam syariah Islam-di samping dua hal tersebut-ditambah lagi dengan adanya kewajiban zakat dan larangan mendiamkan asset.

Menurut kaidah ushul fiqih, harus pula dikemukakan bahwa inflasi tidak dapat dijadikan sebagai illat dalam hukum. Terakhir, pada zaman Rasulullah saw. pun telah terajadi inflasi (seperti dianalisis dengan sangat tajam oleh Ibnu Taimiyyah dan Ibnul-Qayyim dalam kitab mereka; al-Hisbah fil-Islam dan I'lam al-Muwaqqiin), tetapi Rasulullah tidak pernah membenarkan pengambilan bunga pinjaman atas dasar faktor ini.

Menurut Llewellyu dan Hefferman (dalam Yusuf, 2009) hubungan jumlah kredit yang disalurkan dengan tingkat suku bunga memiliki hubungan negatif, yang bermakna bahwa semakin rendah tingkat suku bunga maka semakin besar jumlah kredit yang disalurkan. Hal ini didukung oleh penelitian terdahulu yaitu 
penelitian Kadek Sri Suarni, dkk. (2014) Dengan hasil bahwa suku bunga berpengaruh negaif terhadap kredit artinya apabila suku bunga naik maka jumlah kredit yang disalurkan atau diambil menurun sebaliknya apabila suku bunga turun jumlah kredit akan meningkat.

Pengamatan yang dilakukan di lembaga perbankan diketahui permintaan kredit selalu berubah tergantung pada bebeapa hal antara lain: sukubunga, pendapatan, status pekerjaaan, dan jangka waktu kedit Suku bunga merupakan salah satu faktor yang perlu dipertimbangkan dalam rangka menghimpun dan menyalurkan dana pada masyarakat.

Sesuai dengan pernyataan diatas, Fitri Ratna Sari (2014) meneliti mengenai faktor-faktor yang mempengaruhi keputusan nasabah dalam mengambil kredit di Bank, variabel bebas yang dipakai adalah tingkat suku bunga kredit, Pelayanan, Prosedur Pelayanan Kredit, Jangka Waktu Pengembalian kredit, Jaminan Kredit, sedangkan variabel terikatnya adalah keputusan nasabah. Dan hasil menunjukkan bahwa tingkat suku bunga kredit ikut berpengaruh atau hal yang perlu dipertimbangkan dalam memutuskan pengambilan kredit di bank.

Kehadiran perbankan di Indonesia diperlukan guna ikut mengontrol laju inflasi yang terjadi di Indonesia. Karena hasil penelitian menunjukkan bahwa kredit turut mempengaruhi inflasi. Kartika Andini (2010) Tingkat Suku Bunga Kredit, Tingkat inflasi, Simpanan nasabah sebagai variabel bebas dan variabel terikatnya adalah Kredit investasi. Hasil menunjukkan bahwa inflasi berpengaruh terhadap kredit investasi sedangkan suku bunga tidak berpengaruh terhadap kredit investasi dikarenakan nasabah akan tetap mengambil kredit untuk mengembangkan usahanya.

Menurut Mankiw (2003:58) secara teori tingkat bunga yang dibayarkan bank adalah tingkat bunga nominal yang merupakan penjumlahan tingkat bunga riil ditambah inflasi. Adanya kenaikan atau penurunan inflasi akan berdampak pada kenaikan atau penurunan tingkat bunga kredit. Suku bunga dan inflasi menjadi dua faktor penting yang mempengaruhi aktivitas penyaluran kredit.

Menurut Llewellyu dan Hefferman (dalam Yusuf, 2009) hubungan jumlah kredit yang disalurkan dengan tingkat suku bunga memiliki hubungan negatif, yang bermakna bahwa semakin rendah tingkat suku bunga maka semakin besar jumlah kredit yang disalurkan.

Dari latar belakang diatas merumuskan yang membuat peneliti ingin melihat perbandingan pengaruh inflasi, suku bunga terhadap kredit bank pada bank konvensional dan bank syariah.

\section{Inflasi}

Menurut Latumaerissa (22:2013) definisi singkat dari inflasi adalah kecenderungan dari harga-harga untuk menaik secara terus menerus. Kenaikan dari satu atau dua jenis barang saja dan tidak menyeret harga barang lain tidak bisa disebut sebagai inflasi.

Menurut Bodie dan Marcus (2001:331) inflasi merupakan suatu nilai di mana tingkat harga barang dan jasa secara umum mengalami kenaikan. Inflasi adalah salah satu peristiwa moneter yang menunjukkan suatu kecenderungan akan naiknya harga-harga barang secara umum, yang berarti terjadinya penurunan nilai uang.

Menurut Nopirin (1987:25) inflasi adalah proses kenaikan harga-harga umum barang-barang secara terus menerus. Ini tidak berarti bahwa harga-harga berbagai macam barang itu naik dengan presentase yang sama. Mungkin dapat terjadi kenaikan tersebut tidaklah bersamaan.Kenaikan yang hanya sekali saja (meskipun dengan presentase yang cukup besar) bukanlah merupakan inflasi.

Sedangkan menurut Badan Pusat Statistik (BPS) Inflasi adalahKenaikan harga barang dan jasa secara umum dimana barang dan jasa tersebut merupakan kebutuhan pokok masyarakat atau turunnya daya jual mata uang suatu negara. (http://www.bps.go.id/ Subjek/view/id/3)

\section{Suku bunga}

Menurut Karl dan Fair (2001:635) suku bunga adalah pembayaran bunga tahunan dari suatu pinjaman, dalam bentuk persentase dari pinjaman yang diperoleh dari jumlah bunga yang diterima tiap tahun dibagi dengan jumlah pinjaman.

Pengertian suku bunga menurut Sunariyah (2004: 80) adalah harga dari pinjaman.Suku bunga dinyatakan sebagai persentase uang pokok per unit waktu.Bunga merupakan suatu ukuran harga sumber daya yang digunakan oleh debitur yang harus dibayarkan kepada kreditur.

Menurut Lipsey, Ragan, dan Courant (1997:471) suku bunga adalah harga yang dibayarkan untuk satuan mata uang yang dipinjam pada periode waktu tertentu.

Menurut Samuelson dan Nordhaus (1998) suku bunga adalah pembayaran yang dilakukan atas penggunaan sejumlah uang. 
Menurut Nopirin (1992:176) fungsi tingkat bunga dalam perekonomian yaitu alokasi faktor produksi untuk menghasilkan barang dan jasa yang dipakai sekarang dan di kemudian hari.Menurut Ramirez dan Khan (1999) ada dua jenis faktor yang menentukan nilai suku bunga, yaitu faktor internal dan eksternal. Faktor internal meliputi pendapatan nasional, jumlah uang beredar, dan inflasi. Sedang faktor eksternal merupakan suku bunga luar negeri dan tingkat perubahan nilai valuta asing yang diduga.

Menurut Boedinono (2014) Pengertian tingkat bunga sebagai "harga" ini bisa juga dinyatakan sebagai harga yang harus dibayar apabila terjadi "pertukaran" antara satu rupiah sekarang dengan satu rupiah nanti. Dalam mashab klasik menekankan bahwa bunga timbul karena karena uang adalah "produktif", dalam arti bahwa dengan dana ditangan seorang pengusaha bisa menambah alat produksinya (modal) yang bisa menghasilkan keuntungan lebih tinggi. Dengan perkataan lain, uang bisa meningkatkan produktivitas, karena adanya kenaikan produktivitas inilah orang mau membayar bunga. Menurut mashab Keynesian, uang bisa "produktif" dengan cara lain. Dengan uang tunai di tangan orang bisa berspekulasi di pasar surat-berharga dengan kemungkinan memperoleh keuntungan. Dan karena adanya kemungkinan keuntungan ini orang mau membayar bunga. Dari kedua mashab tersebut dapat disimpulkan bahwa tingkat Bunga adalah "harga uang" yang timbul dari keseimbangan antara permintaan dan penawaran dana investasi (loanable funds). Tingkat bunga adalah juga "harga uang" yang timbul dari keseimbangan antara permintaan dan penawaran uang sebagai aktiva likuid.

\section{Kredit}

Kata dasar kredit berasal dari bahasa Latin credere yang berarti kepercayaan, atau credo yang berarti saya percaya (Firdaus dan Ariyanti, 2009:1). Mac Leod mendefinisikan pengertian kredit sebagai berikut (Firdaus dan Ariyanti, 2009:2): Kredit adalah suatu reputasi yang dimiliki seseorang yang memungkinkan ia bisa memperoleh uang, barang-barang atau tenaga kerja, dengan jalan menukarkannya dengan suatu perjanjian untuk membayarnya disuatu waktu yang akan datang.

Dalam Undang-Undang No. 10/1998 (pasal 21 ayat 11), kredit adalah penyediaan uang atau tagihan yang dapat dipersamakan dengan itu berdasarkan persetujuan atau kesepakatan pinjam meminjam antara bank dengan pihak yang lain yang mewajibkan pihak peminjam untuk melunasi utangnya setelah jangka waktu tertentu dengan pemberian bunga.

Menurut Undang-Undang Perbankan Nomor 10 tahun 1998 (pasal 21 ayat 11) Tentang Perubahan Undang-Undang No. 7/1992 Tentang Perbankan, Kredit adalah penyediaan uang atau tagihan yang dapat dipersamakan dengan itu, berdasarkan persetujuan atau kesepakatan pinjam meminjam antara bank dengan pihak lain yang mewajibkan pihak peminjam melunasi utangnya setelah jangka waktu tertentu dengan pemberian bunga.

\section{Pembiayaan}

Menurut Kasmir (2004:92) pembiayaan adalah penyediaan uang atau tagihan yang dapat dipersamakan dengan itu berdasarkan persetujuan atau kesepakatan antara bank dan pihak lainyang mewajibkan pihak yang dibiayai untuk mengembalikan uang atau tagihan tersebut setelah jangka waktu tertentu dengan imbalan atau bagi hasil.

Menurut Muhammad (2005:17) pembiayaan atau financing yaitu pendanaan yang diberikan oleh suatu pihak kepada pihak lain untuk mendukung investasi yang telah direncanakan, baik dilakukan sendiri maupun lembaga. Dengan kata lain pembiayaan adalah pendanaan yang dikeluarkan untuk mendukung investasi yang telah direncanakan.

\section{METODE PENELITIAN}

Penelitian ini dilakukan pada perusahaan bank konvensional dan Bank Umum Syariah yaitu dengan mengambil data laporan keuangan triwulan I sampai IV periode 2011-2015.

Adapun populasi yang diambil dalam penelitian ini adalah seluruh bank umum konvensional yang memiliki cabang pada bank umum syariah.Karena disini peneliti ingin membandingkan antara kredit di bank konvensional dan pembiayaan pada bank umum syraiah.

Teknik pengambilan sampel yang digunakan dalam penelitian ini adalah dengan menggunakan teknik Purposive Sampling. Dimana teknik ini termasuk dalam metode penarikan sampel nonprobabilitas (probability sampling), sampel nonprobabilitas adalah teknik pengambilan sampel yang tidak memberi peluang/kesempatan sama bagi setiap unsur atau anggota populasi untuk dipilih menjadi sampel (Sugiyono, 2013:84). Sedangkan penarikan sampel purposive (purposive sampling) adalah penarikan sampel dengan pertimbangan tertentu. Dalam teknik 
ini peneliti mengkhususkan lagi pada cara judgment sampling yaitu penarikan sampel berdasarkan penilaian terhadap karakteristik anggota sampel yang disesuaikan dengan tujuan penelitian (Surharyadi, 2009: 17).

Adapun sampel yang digunakan dalam penelitian ini adalah bank umum konvensional yang memiliki cabang pada bank umum syariah.Selain itu sampel yang diambil juga pada bank yang mencantumkan laporan keuangan triwulan I-IV periode 2011-2015. Jenis data yang digunakan dalam penelitian ini adalah data kuantitatif. Data kuantitatif adalah adalah data yang diukur dalam suatu skala numerik (angka) (Yusi, 2010:4).

\section{HASIL DAN pEMBAHASAN}

\section{Hasil}

Setelah terpenuhinya uji normalitas dan linieritas pada data maka langkah selanjutnya dilakukan pertama kali adalah uji signifikansi pada model substruktur 1 dan 2 tehadap masing-masing bank konvensional dan bank syariah yang bertujuan untuk mencari variabel mana sajakah yang signifikan dan non signifikan antara variabel prediktor (eksogen) terhadap variabel tergantung (endogen).
Dari gambar 1 terdapat koefisien jalur pada masing-masing variabel prediktor terhadap variabel tergantung sehingga dapat kita lihat effek dari koefisien jalur pada kolomstandardized coefficients Beta sebagai berikut:

Pengaruh langsung (direct effect):

- $\quad$ Suku bunga $(\mathrm{X}) \rightarrow$ Jumlah kredit $\left(\mathrm{Y}_{2}\right)=0,237$

- $\quad$ Suku bunga $(\mathrm{X}) \rightarrow$ Inflasi $\left(\mathrm{Y}_{1}\right)=0,625$

- $\quad$ Inflasi $\left(\mathrm{Y}_{1}\right) \rightarrow$ Jumlah Kredit $\left(\mathrm{Y}_{2}\right)=0,000$

Pengaruh Tak Langsung (indirect effect):

- Suku bunga $(\mathrm{X}) \rightarrow$ Inflasi $\left(\mathrm{Y}_{1}\right) \rightarrow$ Jumlah kredit $\left(\mathrm{Y}_{2}\right)=(0,625 * 0,000)=0,000$

Dari gambar 2 terdapat koefisien jalur pada masing-masing variabel prediktor terhadap variabel tergantung sehingga dapat kita lihat effek dari koefisien jalur pada kolom standardized coefficients Beta sebagai berikut:

Pengaruh langsung (direct effect):

- $\quad$ Suku bunga $(\mathrm{X}) \rightarrow$ Jumlah pembiayaan $\left(\mathrm{Y}_{2}\right)=$ 0,146

- $\quad$ Suku bunga $(X) \rightarrow \operatorname{Inflasi}\left(\mathrm{Y}_{1}\right)=0,625$

- $\operatorname{Inflasi}\left(\mathrm{Y}_{1}\right) \rightarrow$ Jumlah pembiayaan $\left(\mathrm{Y}_{2}\right)=-0,024$ Pengaruh Tak Langsung (indirect effect):

- Suku bunga(X) $\rightarrow$ Inflasi $\left(\mathrm{Y}_{1}\right) \rightarrow$ Jumlah pembiayaan $\left(\mathrm{Y}_{2}\right)=(0,625 *-0,024)=-0,015$

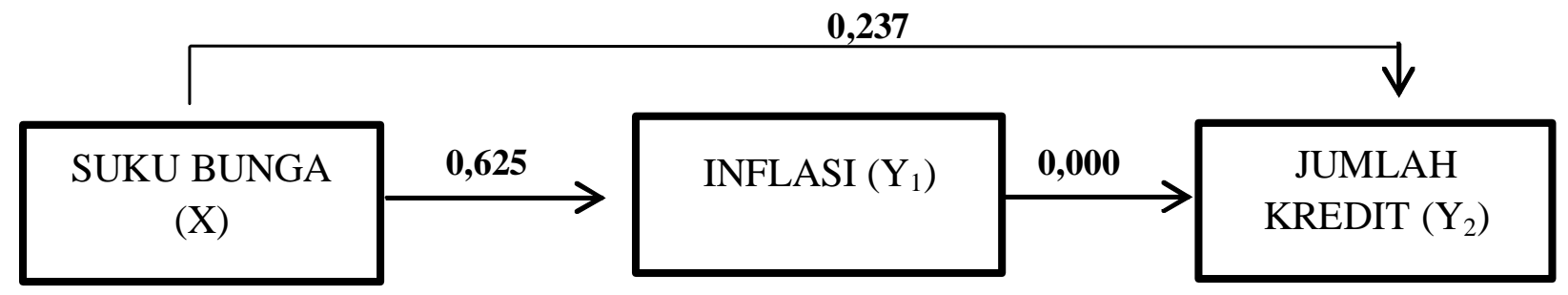

Gambar 1. Model Jalur Substruktur 1 \& 2 Bank Konvensional

Tabel 1. Uji Signifikansi dan Standardized Coefficients Beta

\begin{tabular}{clcc}
\hline NO. & \multicolumn{1}{c}{ Uji Signifikansi } & $\begin{array}{c}\text { Standardized } \\
\text { Coefficients Beta }\end{array}$ & Signifikansi \\
\hline 1. & Suku Bunga $\rightarrow$ Inflasi & 0.625 & 0.000 \\
2. & Suku Bunga $\rightarrow$ Jumlah Kredit & 0.237 & 0.041 \\
3. & Inflasi $\rightarrow$ Jumlah Kredit & 0.000 & 0.993 \\
\hline
\end{tabular}

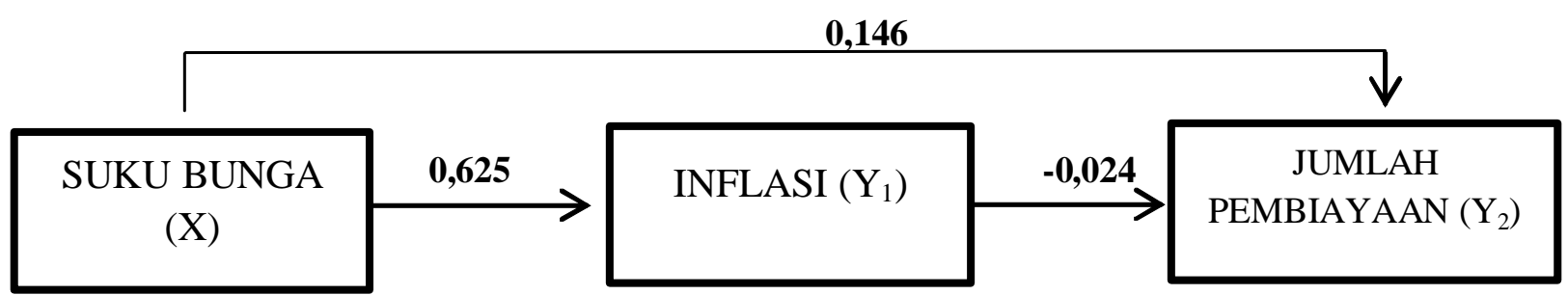

Gambar 2. Model Jalur Substruktur 1 \& 2 pada Bank Syariah 
Tabel 2. Uji Signifikansi dan Standardized Coefficients Beta

\begin{tabular}{clcc}
\hline NO. & \multicolumn{1}{c}{ Uji Signifikansi } & $\begin{array}{c}\text { Standardized } \\
\text { Coefficients Beta }\end{array}$ & Signifikansi \\
\hline 1. & Suku Bunga $\rightarrow$ Inflasi & 0.625 & 0.000 \\
2. & Suku Bunga $\rightarrow$ Jumlah Pembiayaan & 0.146 & 0.215 \\
3. & Inflasi $\rightarrow$ Jumlah Pembiayaan & -0.024 & 0.836 \\
\hline
\end{tabular}

Dari kedua hasil di atas diketahui tingkat beta atau pengaruh.langsung sedangkan pada tingkat signifikansi akan dijelaskan pada tabel 3 .

Tabel 3. Model Substruktur Variabel

\begin{tabular}{|c|c|c|c|}
\hline MODEL & SUBSTRUKTUR & VARIABEL & KETERANGAN \\
\hline \multirow[t]{2}{*}{$\begin{array}{c}1 \\
\text { (Bank Konvensional) }\end{array}$} & Substruktur 1 & Suku Bunga $\rightarrow$ Inflasi & Signifikan \\
\hline & Substruktur 2 & $\begin{array}{c}\text { Suku Bunga } \rightarrow \text { Jumlah } \\
\text { Kredit }\end{array}$ & Signifikan \\
\hline \multirow[t]{3}{*}{$\begin{array}{c}2 \\
\text { (Bank Syariah) }\end{array}$} & Substruktur 1 & $\begin{array}{l}\text { Inflasi } \rightarrow \text { Jumlah Kredit } \\
\text { Suku Bunga } \rightarrow \text { Inflasi }\end{array}$ & $\begin{array}{l}\text { Tidak Signifikan } \\
\text { Signifikan }\end{array}$ \\
\hline & Substruktur 2 & $\begin{array}{c}\text { Suku Bunga } \rightarrow \text { Jumlah } \\
\text { Pembiayaan }\end{array}$ & Tidak Signifikan \\
\hline & & $\begin{array}{l}\text { Inflasi } \rightarrow \text { Jumlah } \\
\text { Pembiayaan }\end{array}$ & Tidak Signfikan \\
\hline
\end{tabular}

\section{PEMBAHASAN}

\section{Bank Konvensional}

Menurut Bodie dan Marcus (2001:331) inflasi merupakan suatu nilai di mana tingkat harga barang dan jasa secara umum mengalami kenaikan.Salah satu kebijakan pemerintah untuk mengendalikaninflasi adalah dengan menaikkan tingkat suku bunga.Menurut Prasetiantono (2000: 99-101) mengenai suku bunga adalah: jika suku bunga tinggi, otomatis orang akan lebih suka menyimpan dananya di bank karena ia dapat mengharapkan pengembalian yang menguntungkan. Dan pada posisi ini, permintaan masyarakat untuk memegang uang tunai menjadi lebih rendah karena mereka sibuk mengalokasikannya ke dalam bentuk portfolio perbankan (deposito dan tabungan).Seiring dengan berkurangnya jumlah uang beredar, gairah belanja pun menurun. Selanjutnya harga barang dan jasa umum akan cenderung stagnan, atau tidak terjadi dorongan inflasi.

Hal ini juga didukung oleh hasil penelitian Hossein, yang menyatakan hasil bahwa bank harus mengurangi suku bunga untuk mengurangi inflasi. Artinya suku bunga berpengaruh positif signifikan terhadap inflasi. Menurut Boediono (2014), Bagi kreditur maupun debitur tingkat bunga riil (yang diharapkan) adalah yang relevan dalam memutuskan apakah mereka akan mengadakan transaksi atau tidak. Bagi kreditur, tingkat bunga riil merupakan imbalan riil bagi pengorbanannya untuk menyerahkan penggunaan uangnya untuk jangka waktu tertentu. Bagi debitur, tingkat bunga riil merupakan beban riil atas penggunaan uang orang lain.

Menurut Karl dan Fair (2001:635) suku bunga adalah pembayaran bunga tahunan dari suatu pinjaman, dalam bentuk persentase dari pinjaman yang diperoleh dari jumlah bunga yang diterima tiap tahun dibagi dengan jumlah pinjaman. Fungsi dari suku bunga menurut Sunariyah (2004:81) salah satunya adalah dapat digunakan sebagai alat moneter dalam rangka mengendalikan penawaran dan permintaan uang yang beredar dalam suatu perekonomian. Misalnya, pemerintah mendukung pertumbuhan suatu sektor industri tertentu apabila perusahaan-perusahaan dari industri tersebut akan meminjam dana. Maka pemerintah memberi tingkat bunga yang lebih rendah dibandingkan sektor lain. Jadi suku bunga berbanding terbalik pada jumlah penyaluran kredit yang ada di perbankan. Semakin rendah tingkat suku bunga semakin besar penyaluran kredit, dan sebaliknya.

Berdasarkan penelitian yang dilakuka oleh Tenda (2014) menjelaskan bahwa suku bunga berpengaruh negative signifikan terhadap kredit investasi. Hasil ini juga sama dengan penelitian yang dilakukan oleh sari bahwa suku bunga memiliki pengaruh yang signifikan terhadap kredit. sedangkan penelitian yang dilakukan 
oleh Pratama (2010) menyatakan bahwa suku bunga berpengaruh positif tidak signifikan terhadap kredit di bank umum di Indonesia. Berbeda dengan penelitian yang dilakukan oleh Merung (2013) yang menyatakan bahwa suku bunga tidak berpengaruh signifikan terhadap kredit.

\section{Bank Syariah}

Menurut Karim (2011:41), dari definisi riba, dan tujuan (hikmah) pelarangan riba, maka dapat diidentifikasi praktik perbankan konvensional yang tergolong riba. Riba Fadl dapat ditemui dalam transaksi jual beli valuta asing yang tidak dilakukan secara tunai. Riba nasi'ah dapat ditemui dalam transaksi pembayaran bunga kredit dan pembayaran bunga tabungan/ deposito/giro. Riba jahiliyah dapat ditemui dalam transaksi kartu kredit yang tidak dibayar penuh tagihannya.

Kasmir (2012:114) mengungkapkan bunga bank dapat diartikan sebagai balas jasa oleh bank yang berdasarkan prinsip konvensional kepada nasabah yang membeli atau menjual produknya. Bunga juga dapat diartikan sebagai harga yang harus dibayar kepada nasabah (yang memiliki simpanan) yang harus dibayar nasabah kepada bank (nasabah yang memperoleh pinjaman). Menurut Mankiw (2003) secara teori tingkat bunga yang dibayarkan bank adalah tingkat bunga nominal yang merupakan penjumlahan tingkat bunga riil ditambah inflasi. Adanya kenaikan suku bunga juga akan mempengaruhi penyaluran kredit di bank konvensional dan pembiayaan di bank syariah, karena kenaikan suku bunga juga akan mempengaruhi tingkat bagi hasil yang ada di bank syariah baik secara langsung maupun tidak langsung. Semakin tinggi suku bunga maka maka akan menurunkan perimntaan masyarakat terhadap pembiayaan, sehingga pembiayaan yang dikeluarkan oleh bank juga semakin sedikit.

Ini didasarkan penelitian yang dilakukan oleh Azmy (2010) yang menyatakan bahwa suku bunga berpengaruh terhadap pembiayaan. Ini juga didukung oleh penelitian yang dilakukan oleh Sari (2013) yang menyatakan bahwa suku bunga berpengaruh signifikan terhadap kredit di bank umum di Indonesia. sedangkan penelitian yang dilakukan oleh Pratama (2010) menyatakan bahwa suku bunga berpengaruh positif tidak signifikan terhadap kredit di bank umum di Indonesia. berbeda dengan penelitian yang dilakukan oleh Merung (2013) yang menyatakan bahwa suku bunga tidak berpengaruh signifikan terhadap kredit.
Menurut (Mankiw, 2003) secara teori tingkat bunga yang dibayarkan bank adalah tingkat bunga nominal yang merupakan penjumlahan tingkat bunga riil ditambah inflasi. Adanya kenaikan atau penurunan inflasi akan berdampak pada kenaikan atau penurunan tingkat bunga kredit. Suku bunga dan dan inflasi menjadi dua faktor penting yang mempengaruhi aktivitas penyaluran kredit. Jika inflasi tinggi, maka suku bunga kredit juga akan naik. Naiknya suku bunga juga akan mempengaruhi nilai bagi hasil pada perbankan syariah. Ini menyebabkan masyarakat tidak mau mengambil kredit di bank atau pembiayaan di bank syariah, karena bunga yang terlalu tinggi.

Hal ini didukung oleh hasil penelitian Cahya (2013) yang menunjukkan bahwa secara parsial variabel independen NPF, DPK, dan Inflasi berpengaruh terhadap pembiayaan UKM.Secara simultan, DPK berpengaruh positif dan signifikan terhadap penyaluran pembiayaan UKM. Sedangkan inflasi tidak berpengaruh terhadap pembiayaan UKM. Hasil koefisien determinasi $\left(\mathrm{R}^{2}\right)$ menunjukkan $98,6 \%$ di mana penyaluran pembiayaan UKM (Y) dapat dijelaskan oleh variabel independen NPF $\left(\mathrm{X}_{1}\right)$, DPK $\left(\mathrm{X}_{2}\right)$, dan inflasi $\left(\mathrm{X}_{3}\right)$. Sedangkan $1,4 \%$ adalah oengaruh dari variabel bebas lainnya yang tidak dijelaskan dalam model penelitian.

Ini bertolak belakang dengan hasil pada penelitian yang dilakukan Tohari (2010) yang menyatakan bahwa inflasi berpengaruh negatif signifikan terhadap pembiayaan di bank syariah. Ini berarti semakin tinggi inflasi, semakin rendah permintaan pembiayaan.Ini berbeda dengan penelitian yang dilakukan oleh Fahrudin (2009) dari hasil penelitian ini menunjukkan bahwa inflasi berpengaruh positif signifikan terhadap penyaluran pembiayaan.Adapun berbeda juga dengan penelitian yang dilakukan oleh Tadris, Tomy dan Murni (2015) yang menyatakan bahwa inflasi tidak berpengaruh terhadap kredit di perbankan di Manado.Dan dalam penelitian Firaldi (2013) juga menyatakan bahwa inflasi tidak berpengaruh terhadap pembiayaan di BPR Syariah.

Menurut (Mankiw, 2003) secara teori tingkat bunga yang dibayarkan bank adalah tingkat bunga nominal yang merupakan penjumlahan tingkat bunga riil ditambah inflasi. Adanya kenaikan atau penurunan inflasi akan berdampak pada kenaikan atau penurunan tingkat bunga kredit. Suku bunga dan dan inflasi menjadi dua faktor penting yang mempengaruhi aktivitas penyaluran kredit. Jika inflasi tinggi, maka suku bunga kredit juga akan naik. Naiknya suku bunga juga 
akan mempengaruhi nilai bagi hasil pada perbankan syariah. Ini menyebabkan masyarakat tidak mau mengambil kredit di bank, karena bunga yang terlalu tinggi.

Ini didasarkan pada penelitian yang dilakukan Tohari (2010) yang menyatakan bahwa inflasi berpengaruh negatif signifikan terhadap pembiayaan di bank syariah.Ini berarti semakin tinggi inflasi, semakin rendah permintaan pembiayaan.Ini berbeda dengan penelitian yang dilakukan oleh Fahrudin (2009) dari hasil penelitian ini menunjukkan bahwa inflasi berpengaruh positif signifikan terhadap penyaluran pembiayaan. Adapun berbeda juga dengan penelitian yang dilakukan oleh Tadris, Tomy dan Murni (2015) yang menyatakan bahwa inflasi tidak berpengaruh terhadap kredit di perbankan di Manado.Dan dalam penelitian Firaldi (2013) juga menyatakan bahwa inflasi tidak berpengaruh terhadap pembiayaan di BPR Syariah.

\section{KESIMPULAN DAN SARAN}

\section{Kesimpulan}

Dari hasil dan pembahasan yang telah dipaparkan dalam bab sebelumnya maka dapat peneliti simpulkan: Dari hipotesis I, hasil menunjukkan tingkat signifikansi suku bunga sebesar 0,041. Dapat dijelaskan bahwa tingkat signifikan sebesar 0,041 <0,05 $(\alpha)$. Artinya bahwa suku bunga berpengaruh signifikan terhadap jumlah kredit Maka $\mathrm{H}_{1}$ diterima dan $\mathrm{H}_{0}$ ditolak. Hipotesis II menunjukkan bahwa tingkat suku bunga $(\mathrm{X})$ signifikan terhadap inflasi $\left(\mathrm{Y}_{1}\right)$ tetapi inflasi $\left(\mathrm{Y}_{1}\right)$ tidak signifikan terhadap kredit $\left(\mathrm{Y}_{2}\right)$. Sehingga hipotesis II tidak dapat dilakukan, dengan kata lain inflasi gagal sebagai variabel intervening sehingga $\mathrm{H}_{2}$ ditolak dan $\mathrm{H}_{\mathrm{o}}$ diterima. Hipotesis III menunjukkan inflasi memiliki tingkat signifikansi sebesar 0,993>0,05 $(\alpha)$. Artinya Inflasi tidak berpengaruh signifikan terhadap jumlah kredit. Sehingga $\mathrm{H}_{3}$ ditolak dan $\mathrm{H}_{0}$ diterima. Hipotesis IVmenunjukkan tingkat signifikansi suku bunga sebesar 0,215. Dapat dijelaskan bahwa tingkat signifikan sebesar 0,215>0,05 $(\alpha)$. Artinya bahwa suku bunga tidak berpengaruh signifikan terhadap jumlah pembiayaan $\mathrm{Maka}_{4}$ ditolak dan $\mathrm{H}_{0}$ diterima.
Hipotesis V menunjukkan bahwa tingkat suku bunga $(\mathrm{X})$ signifikan terhadap inflasi $\left(\mathrm{Y}_{1}\right)$ tetapi inflasi $\left(\mathrm{Y}_{1}\right)$ tidak signifikan terhadap pembiayaan $\left(\mathrm{Y}_{2}\right)$. Sehingga hipotesis tidak dapat dilakukan, dengan kata lain inflasi gagal sebagai variabel intervening sehingga $\mathrm{H}_{5}$ ditolak dan $\mathrm{H}_{\mathrm{o}}$ diterima. Dan hipotesis VI menunjukkan inflasi memiliki tingkat signifikansi sebesar 0,836>0,05 $(\alpha)$. Artinya Inflasi tidak berpengaruh signifikan terhadap jumlah pembiayaan.Sehingga $\mathrm{H}_{5}$ ditolak dan $\mathrm{H}_{0}$ diterima.

\section{Saran}

Adapun saran bagi peneliti lanjutan adalah menambahkan variabel-variabel prediksi yang mempengaruhi variabel terikait dan menambahkan populasi dan sampel pada bank konvensional dan bank syariah untuk memberikan prediksi yang tepat pada hasil dan model.

\section{DAFTAR RUJUKAN}

Boediono. 2014. Ekonomi Moneter. Edisi Ketiga. Yogyakarta: BPFE-Yogyakarta.

Karim, Adiwarman, A. 2011. BANK ISLAM Analisis Fiqih dan Keuangan, Edisi Empat. Jakarta: Rajawali Press.

Karl, E., Case, and Fair, C. Rai. 2001. Prinsip-prinsip Ekonomi Makro. Jakarta: Prenhalindo.

Latumaerissa, Julius, R. 2013. Bank dan Lembaga Keuangan Lain. Jakarta: Salemba Empat.

Lipsey, Ragan, dan Courant. 1997. Suku Bunga, Harga yang Dibayarkan untuk Satuan Mata Uang yang Dipinjam pada Periode Waktu. Jakarta: Erlangga.

Nopirin. 1987. Ekonomi Moneter. Buku II, Edisi I. Yogyakarta: BPFE.

Nopirin. 1992. Ekonomi Moneter, Buku II, Edisi I. Yogyakarta: BPFE.

Sugiyono. 2013. "Metode Penelitian Kuantitatif Kualitatif dan $R \& D$ \&. Bandung: Alfabeta.

Sunariyah. 2004. Pengantar Pengetahuan Pasar Modal. Edisi Keempat. Yogyakarta: UMPAMPYKPN.

Surhayadi, Purwanto. 2009. Buku 2. "Statistika untuk Ekonomi dan Keuangan Modern”. Jakarta: Salemba Empat.

Yusi, Syahirman, etc. 2010. "Statistika untuk Ekonomi dan Penelitian”. Palembang: Citra Book Indonesia. 